\title{
Role of Tendering Process on Performance of Public Institutions: A Case Study of Nakuru County Government
}

\section{Eunice Waruguru}

Department of Accounting, Finance and Management Science, Egerton University, Nakuru, Kenya

\section{Email address:}

yunnywa@yahoo.com

\section{To cite this article:}

Eunice Waruguru. Role of Tendering Process on Performance of Public Institutions: A Case Study of Nakuru County Government. International Journal of Economics, Finance and Management Sciences. Vol. 3, No. 4, 2015, pp. 391-405. doi: 10.11648/j.ijefm.20150304.17

\begin{abstract}
The purpose of the study was to determine the role of tendering process on performance of public institutions. The study was guided by the following specific objectives. To assess the role of transparency resulting from tendering process on the performance of public institutions, to establish the role of accountability resulting from tendering process on the performance of public institutions, to find out the role of quality resulting from tendering process on the performance of public institutions, to determine the role of lead time resulting from tendering process on the performance of public institution. A case study design was adopted for the study. The study targeted 43 procurement officers from 10 ministries in Nakuru County Headquarters. Census technique was applied. Questionnaires were used to collect data. Data analysis was done using descriptive and inferential statistics. The findings revealed that the level of transparency in the county government was good. They further revealed that transparency reduced corruption during tendering process hence resulting to enhanced performance in public institutions. Further the researcher found out that Public administration on tendering process leads to accountability during the tendering process and hence positive performance of public institutions. The research findings also revealed that high lead time variability due to tendering was a major reason for the institutions inability to achieve inventory goals and hence affecting the performance of public institutions negatively. Based on the findings, the researcher recommended that the organization employees to be more transparent in the tendering process, the organization puts in place measures to enhance transparency during the process and also to minimize lead time to enhance the speedy delivery in the organization and thus enhance overall organization performance of the organization. The researcher recommended a further research to be carried out on the role played of other alternative procurement methods on performance of public institutions. Further studies should be conducted on the critical success factors of tendering in public institutions.
\end{abstract}

Keywords: E-Procurement, Business Organizations, Nakuru CBD

\section{Introduction}

\subsection{Background of the Study}

Public procurement is the process by which public entities contract for acquisition/supply of goods services or wants and disposal of public goods in accordance to the current legal framework of Public Procurement and Disposal Act (PPDA 2005).

Public procurement can also be referred to as the procurement of goods and services on behalf of the authority e.g. government agency. It's the awarding of contracts for public works and purchase of goods by the public authority. Public procurement is different from private procurement.

In public procurement the economic results must be measured against more complex and long term criteria.
Furthermore public procurement is transacted with other considerations in mind, besides the economy. These considerations include accountability, non-discrimination among potential suppliers and respect for international obligations. For these reasons, public procurement is subjected in all countries to enacted regulations in order to protect the public interests. It's worth noting that unlike private procurement, public procurement is a business process within a political system and has therefore significant consideration of integrity accountability national interest and effectiveness. (Wittig 2002)

Public procurement covers the management of supply on public institutions and agencies as well as publicly owned entities. Taxes represent a major source of the funds extended in public supply. These taxes are sourced from the public through the economy's revenue collection authority. The 
objectives of a sound supply management in the public sector are basically the same as for the supply in the private sector: effective contribution to organizational goals and assurance of value for money spent. However, the unique environment in which public procurement operates represents special challenges. In every country the public buyer is subjected to special laws, rules and regulations and is ever mindful of the politically dictated targets while open to public scrutiny. Public procurement agencies in the industrial world, including United States, the United Kingdom, Canada, Australia, the European Union or even Kenya, share similar supply experiences whether buying pen or paper or even military specified equipment. Similar if not same procedures of procurement exist in almost all these economies although the budgets may vary. There are many different types of public entities and institutions. They include federal states, provincial, county and municipal levels each with wide array of subgroups. Given that in various countries the percentage that the government contributes to the gross domestic product (GDP), range anywhere from 25-50 percent, it's not difficult to envisage the economic and social impact of public supply. Therefore the wise the spending of the taxpayers money ensures that the government services benefit from those intendedand help build taxpayers confidence and trust in government.(Lenders Johnson et al 2006)

Governments all over the world have received a great deal of essential services such as health education, defense and infrastructure. To be able to meet the demand for these services, governments purchases goods and services from the market place. The business operations of the government in the market place or public procurement have thus both economic and political implications. The governments or its agencies through the public procurement, purchase commodities, services, contracts and works by use of public resources. These resources are sourced from state budgets, state foundation funds, domestic loans or foreign loans as well as revenue received from the economic activity of the state. This is to say that public procurement involves the use of public funds (Wittig 2002).

The public procurement system in Kenya has evolved overtime from a crude system with no regulation to the current orderly and legally regulated system. Initial regulations were contained in the supplies manual of 1978 and supplemented by circulars that were issued from time to time by treasury. The director of government supply agencies was responsible for ensuring proper observance of the provisions of the manual. The manual created various tenders and their awards. A review of public procurement system carried out in 1999 unearthed a number of challenges. Among the key flaws noted was no uniform procurement system for the public sector. Besides the system that existed did not have sanctions against persons who breached the regulations in the supplies manual, other than internal disciplinary action. Moreover the supplies manual did not cover problems of works and the disputes settlement mechanisms relating to the award procedures as set out in the manual were weak and unreliable for ensuring fairness and transparency. Records of procurement transactions in most cases were found to be inaccurate or incomplete or absent which led to suspicions of dishonest dealings at the tender boards. In the view of the shortcomings, it was found necessary to have a law to govern the procurement system in the public sector and to establish the necessary institutions to ensure that all procurement entities observed the provisions of the law for the purpose of attaining the objectives of an open tender system in a sector. Consequentially the Exchequer and Audit (Public Procurement Directorate) Regulations 2001 which created the Public Procurement.

\subsection{Problem Statement}

The Government of Kenya has implemented a number of reforms to address inefficiency in the use of public resources and weak institutions of governance. The reforms include the enactment of public and disposal act 2005, Public Officer Ethic's Act 2003 and the Anti-Corruption and Economic Crimes Act. The PPDA 2005 has established procedures for tendering and disposal of unserviceable, obsolete or surplus stores and equipment by public entities to achieve; maximize economy and efficiency, promote competition and ensure competitors are treated fairly, promote the integrity and fairness of those procedures, increase transparency and accountability in those procedures, increase public confidence in the procedure and facilitate the promotion of local industries and economic development. Studies have been conducted on the factors affecting performance of public institutions but despite an increase in knowledge in the tendering process according to PPDA 2005 very little have been done to analyze the role played by tendering process on the efficiency and effectiveness of public procurement. The research therefore sought to establish the role of tendering procedure, tendering committees, ICT application and tender records management influence the performance of public procurement.

\subsection{Specific Objectives}

The main objective of the study was to determine the role of tendering process on performance of public institutions. The specific objectives of the study were:

i. To assess the role of transparency resulting from tendering process on the performance of public institutions.

ii. To establish the role of accountability resulting from tendering process on the performance of public institutions.

iii. To find out the role of quality resulting from tendering process on the performance of public institutions.

iv. To determine the role of lead time resulting from tendering process on the performance of public institution.

\subsection{Research Questions}

The research is guided by the following research questions; i. What is the role of transparency resulting from 
tendering process on the performance of public institutions?

ii. What is the role of accountability resulting from tendering process on the performance of public institutions?

iii. What is role of quality resulting from tendering process on the performance of public institutions?

iv. What is the role of lead time resulting from tendering process on the performance of public institutions?

\subsection{Significance of the Study}

The findings of research is of great benefit to Nakuru County government and other county governments as it will provide part of the evidence to assist in the revision of procurement policies in favor of procurement profession regarding the tendering process in Public Institutions. The research also is beneficial to the body of knowledge in understanding the tendering process in Public entities. This will also benefit other researcher who may want to research more in this area.

\subsection{Limitation of the Study}

The study faced a challenge of some respondents who feared that the information provided may end up not being treated with confidentiality or might end up being misused hence cost them their jobs. To overcome this limitation, the research presented the research letter and additionally assured them that the research is purely for academic purposes. Some respondents were uncooperative. In this case, some respondents decided to ignore to listen to the researcher and even ignored to answer the questionnaire as it may be expected. In this limitation, the researcher tried to make the respondents to understand the reason as to why the study was being carried out.

\subsection{Scope of the Study}

This study was confined to Nakuru County. Data was collected from procurement department in Nakuru County Headquarters in Nakuru town. The study covered a period of three months December 2014 to March 2015 and focused on the role of tendering process on performance of public institutions. The samples were collected from procurement departments. The total target population of the study was 43 employees from procurement department.

\section{Literature Review}

This chapter seeks to review what other scholars and researchers have previously written about the role of tendering process on performance of public institutions. It appreciates what other researchers have contributed towards this area and assesses what need to be researched further. The sources of literature includes; books, internet and research reports. As stated by Mugenda, (1999) the review of literature involves the systematic identification, location and analysis of documents containing information related to research problem being investigated. Literature review enables the researcher to know what has been done in that particular field of study.

\subsection{Review of Empirical Literature}

Gordon, S.P., (1996), points out that tendering process objective may be broad and specific. A classic definition is the competitive and procedural systematic procedure of selecting the best suppliers for the cheapest price. Kibera and Waruingi (2005), in their study on factors affecting tendering process found out those factors like ethical practices, training, ICT use and record management is the key factors that affect tendering process. It is with this perception that the supplies should provide better services to enhance the performance of the tendering process by better displaying these services by having good supplier, good prices good quality, and quick delivery of goods. Most consumers are sensitive to quality than quantity and that is the reason as to why the SME'S should look for the most competitive and reliable source to supply them with the quality goods/services their consumers demand.

Government procurement is one of the four economic activities of government Thai, (2001). The others are: redistributing income through taxation and spending, provision of public goods and services, and lastly providing the legal framework for economic activities to flourish. Ordinarily, government procurement includes "buying, purchasing, renting, leasing or otherwise acquiring any supplies, services or construction;" and "all functions that pertain to the obtaining of any supply, service or construction, including description of requirements, selection, and solicitation of sources, preparation and award of contract and all phases of contract administration" (American Bar Association, 2000). Although, government procurement is still young as an academic discipline, recent literature of public procurement suggests that public procurement practice has undergone major changes particularly in the area of legal reforms. For LDCs, reforms in public procurement have been seen as one of the ways to integrate them into the emerging world economy (OECD Development Centre, (2002).

In order to develop a uniform government procurement practice that can be compared across various public organization, it has become necessary develop formal government procurement codes that contain formal procurement rules and regulations across a number of countries both developed and developing. For the poor developing countries, government procurement regulations and procedures have been one of the reform areas (Thai, 2001; OECD, 2007) since early 2000. By 2003 for instance, all East African Countries, Uganda, Kenya, and Tanzania had enacted government procurement codes as Acts of Parliament and have been implemented since (OECD Development Centre, 2003).

A number of elements can be identified to characterize the public procurement system. Thai (2001) identified five elements that include: policy making and management; procurement regulations or laws; procurement authorization and appropriations; public procurement function or 
operations,; and lastly feedback. According to Thai (2001), the procurement regulations or laws established by policy makers is the institutional framework within which procurement professionals and program managers implement their authorized and funded procurement programs or projects/ activities. Secondly, the policy makers and top government management executives are the custodians of the public procurement laws and regulations and represent the government organs to which procurement professionals, program managers and the managers of all public procurement entities are ultimately accountable.

Similarly, the policy makers and top government management executives are the organs to which feedback that are generated by the procurement professionals/implementers during the course of implementing procurement operations has to be directed for possible adjustments or improvements in both the procurement regulations and authorizations and appropriations. However, feedback is important also for the procurement professionals for adjustments or improvements in procurement operations. Thirdly, the procurement authorization and appropriation element represents the public organs and processes that determine the amount of resources that are available to procurement entities to undertake procurement activities. They are the ultimate assessors of the validity of the procurement needs of public entities through the budget approval processes. Fourthly, the procurement function or operations represent the units composed of procurement professionals that implement procurement operations within the procuring public organizations.

Thai (2001) emphasized the role of feedback in the functioning of the public procurement system and proposed that it represents a distinct element of the public procurement system. As already indicated, Thai (2001) argued that the quality of feedback that is generated by the procurement professionals/implementers during the course of implementing procurement operations is critical for any possible adjustments or improvements in both the procurement regulations and authorizations and appropriations. However, feedback is important also for the procurement professionals for adjustments and improvements in procurement operations.

The business operations of government, as controlled by public procurement systems, affect many different elements of society. The research study is therefore of great importance in various aspects. First to the procuring entities which have the responsibility to perform designated missions for the country as a whole. Then there is the business community of actual or potential suppliers to the government. International organizations and external donors of funds feel satisfied when their funds are used to get the best value. There are also academic, training and public interest groups, which have important views on how public management institutions are to perform. And the largest interest group is the general public, who are more likely to feel satisfaction when they know that expenditures made through the public procurement system are economical, rational and fair. After the research, recommendations for strengthening tendering in public procurement will be evident. The research will be particularly useful to procurement entities in that amendments can be made in the PPDA to better the process of tendering.

Several Organisational factors in the procurement entities seem to be influenced by the legal and national institutional set up of public procurement. These organizational factors include procurement budget adequacy, the requirements for procurement planning, the organisation structure including the definition and re-definition of the roles and responsibilities of different organs within procurement entities. Others include the level of the procurement function within the organizational hierarchy, the length of the procedure for authorization and others. The level of the procurement function within the organizational hierarchy influences the speed at which procurement decisions can be taken and the efficacy of implementation. It has been suggested that the procurement function in operations is the critical and complicated element in the public procurement system.

Furthermore, the law prescribes explicitly or implicitly how organizations should organize and structure to undertake their procurement activities. Through this influence, the procurement legal framework indirectly impacts on the implementation of the procurement process and ultimately the quality of procurement outcomes and the extent to which the objects of the procurement law will be achieved. However, this influence may vary between different organizations or different organization types.

There are currently four different tender procedures the council may use. Restricted tender, suppliers who respond to advertisements expressing an interest in tendering are required to complete a pre-qualification questionnaire to show that they have sufficient shortlisted can be resources to meet the needs of the procurement opportunity. Only suppliers who are subsequently shortlisted can be invited to submit a tender. Open tender, all suppliers who request tender documentation will be invited to submit a tender. There is no pre-qualification questionnaire or short listing stage prior to invitation to tender. This information is requested as part of the tender itself. Known market place is limited. Negotiated tender, is similar to the restricted tender procedure in that it uses a pre-qualification stage. However, it allows the council with strict guidelines prior to awarding the contract. Tender procedures must be clearly set out recorded to ensure evidence of full compliance with the code. Internal or external auditors (Agnes, 2005) should take car regarding the receipt, recording, assessment, and confidentiality of all communication-undertaken at any stage of the tender process.

To ensure that proper recording of submitted tender is carried out, the SP must adopt a formal procedure for the receipt and opening of tenders. If not using the departments in the Health Service or Agency Offices with suitable facilities and processes. The tender opening process requires that an opening panel of at least two persons should be constituted. One of these people must be an officer of the department or agency with knowledge of probity and confidentiality. It is normal practice to have a tender box that can secured (i.e. locked) available until tender close and only tenders received 
ion time shall be considered for evaluation. Tenders for publicity-funded projects shall not be received in consultant's offices. (Mizra 2008)

The date and time for receipts of tenders should be at a pre-determined place, time and day as required by the code and the opening of tenders should record in order of opening the relevant tender summary details. Any tenders received after the nominated date and time shall be marked as such, shall remain unopened and shall be returned to the submitting party. All unsuccessful tenders should also be notified of the outcome following a letter of acceptance being issued. Unsuccessful tenders should be produced with the contract details of a nominated representative of the supplier who can provide feedback. All feedback provided should be positive and relates to the tenders own submission to assist the tender with future tenders. No reference should be made to other submissions other than the name and amount of the successful tender (Mizra 2008).

According to Mufumba (2002), Councilors in Uganda were pushed out of Tendering process. They were not allowed to get involved in the tendering process to avoid possibility of compromising their supervisory eliminate the possibility of shoddy work, since councilors were to find themselves in a position where they have to grill one of their own.

In Russia, the tendering system has also weaknesses. Corruption is invariably associated with Russia's business environment and in, procurement and tendering of huge projects around the world. Although it remains a major problem, corruption in Russia is being tackled and the business environment is improving. Businesses in Russia's can mitigate their risks through simple step and by being alert. (Business, Corruption and Russia 14 March 2012)

In South Africa, according to parliamentary report on service delivery recommendation of 13 September 2010, the tendering process was introducing to eradicate rampant unethical practices that were observed in the country. The government was to tighten the tender system in South Africa's municipalities in order to fight unethical practices, while prosecuting officials who abuse the system "The Tender system in municipalities needed a total turn around."

In Tanzania according to world forum (2012), a total of \& 494 was given from Donors for the Budget Donors pledged to increase aid to Tanzania to \& 495 million for its $2011 / 13$ budget but warned future disbursements could depend on how it tackled corruption and misuse of public funds especially in tendering and procurement, According to Seloba (2006), political interference in Administrative practitioners and politicians due to the amount of money involved.

\subsection{Review of Theoretical Literature}

\subsubsection{Effect of Quality on Organization Performance}

According to Heizer \& Render (2003), quality is the ability of a product or service to meet customer/user needs. Quality can mean excellence, meeting customer requirement, quality as value, customer perception and adoption to expectation. Hansen (2001) lamented that it is unfortunate that until today the concept of quality appear fragmented and ambiguous in literature as in practice. The term quality management has different meaning within many business sectors. It is considered to have four main components: quality planning, quality control, quality assurance and quality improvement. Quality management is focused not only on product/service quality, but also the means to achieve it. Quality management theory focus on continuous improvement therefore uses quality assurance and control of processes as well as products to achieve more consistent quality.

Walter A. Shewhart (2001) made a major step in the evolution towards quality management by creating a method for quality control for production, using statistical methods, first proposed in 1924. This became the foundation for his ongoing work on statistical quality control. W. Edwards Deming later applied statistical process control methods in the United States during World War II, thereby successfully improving quality in the manufacture of munitions and other strategically important products.

Quality management has become such an influential element of doing business that companies have adopted the cost of quality (COQ) model to predict the possible financial burdens of selling a product that is flawed. The COQ recognizes prevention costs, appraisal costs, internal failure, and external costs as foreseeable quality management issues that could not fulfill the needs of the customer.

Furthermore, an international body has come forward to create a unifying single quality standard known as the ISO 9000 , which published a series of quality assurance standards. For a company to become a member of ISO 9000, they must be observed for 9 to 18 months and must meet rigorous quality standards on their goods and services. However, quality control cannot just focus on individual function in order for a procurement manager to be successful they need to implement total quality management (TQM). TQM embodies the entire organization, from supplier to consumer, to follow a stringent quality management emphasis. TQM incorporates a wide range of methods from the plan, do, check, act circular flow model which provides a company a template to have continuous improvement to the six sigma process. Six sigma is a statistical tool that aims to help reduce defects to a $99.9997 \%$ capability rate.

Quality in its most basic sense is making the consumer/user content with their good/service and it is the obligation of the procurement manager to ensure that quality awareness is involved with each decision areas. The European Foundation for Quality Management (EFQM) proposes a model of excellence leading to improved business results. The model is based on the concept that an organization will achieve better results by involving all people in the continuous improvement of their processes. Investors in people have drawn attention to the importance of employees' engagement for building effective relationship between an organization and its people. Cascading the vision and direction of the organization is one of the strongest levers for generating improved performance. (Mullins, 2010)

When the purchasing department is looking at the procurement of materials from suppliers they will have been 
given some guidance by the manufacturing department, research and development, or the quality department. This should include a variety of information about the item to be sourced, such as physical description, dimensional measurements, chemical composition, performance specifications, and standards to conform to, or even the brand name of the product Stiglitz, (2000). The purchasing department must know the physical attributes of the part they are required to source. For example, if the required material must be made of a certain shade of a blue, then the purchasing department must be able to communicate that requirement to the potential suppliers to ensure that the specification can be met. Sometimes the quality department or development team will inform the purchasing department to only source a particular brand name. This may be due to the specific nature of the part made by one company or the level of quality it has over competitors.

The interaction of the procurement legal framework and the quality of the procurement workforce in public procurement entities is in some cases indirect and direct. According to Jensen and Stone Cash (2004), by stipulating the procurement standards and procedures to be complied with, the legal framework indirectly influences the types of competencies of the staff to be put in charge of procurement operations. In some cases, however, such as some procurement legal frameworks in the US, see Illinois Public Higher Education Procurement Bulletin, (2005), the staff competencies are explicitly suggested and by implication the type and quality of staff. According to Thai (2001), ordinarily, the public procurement function should be handled by a professional workforce equipped with needed skills and knowledge through training (Thai, 2001). However, it is also suggested that generally, higher education institutions and educators have not recognized the educational needs of public procurement professionals. Because of this, where a procurement legal framework explicitly provides for public procurement training, it can substantially impact on the quality of procurement professionals manning the procurement operations of public procurement entities.

The quality of procurement and procurement related workforce influences the efficiency of the procurement process and the degree of compliance to procurement laws, regulations and policies. In the end, this influences the quality of procurement outcomes and the achievement of the objects of the procurement law. According to Thai (2001), procurement professionals and personnel have dual responsibilities. They make sure that operational agencies comply with procurement regulations and they are directly involved in procuring goods, services, and capital assets as authorized and funded. As already indicated, procurement professionals through their experience with procurement regulation system are a major source of feedback for procurement adjustment, improvement or reform. In order to do their work effectively, however, procurement professionals have to be well equipped with a set of skills and competencies. In particular, they need to be equipped with procurement techniques and methods and process management skills which are pertinent to their work.

Jensen and Stone Cash (2004), suggests that the core procurement methods and techniques required by procurement professionals include: negotiation skills, price analysis, cost analysis, and procurement cycles. While the procurement cycles vary by the type of procurement, it is always necessary that procurement professionals are conversant with the procurement cycles of the range of goods and services their organization is likely to handle.

Finally, according to Thai (2001), the number of staff in the procurement function in an organization should be sufficient for the procurement task in a specific procurement entity.Although no specific formula is provided, organizations are expected to achieve a balance between the size of the procurement task, probably by the volume and frequency of procurement transactions and the procurement values involved. Thai (2001) alludes to the fact that higher value transactions require more care and time in executing them. This may require more staff where such transactions are relatively frequent.

\subsubsection{Effect of Lead Time on Organization Performance}

Lead time is one of the main competitive factors among companies. The ability to deliver quickly influences export, sales and thereby revenue. The definition of lead-time can vary, depending on what part of the company is focused upon. Lead time begins with the first receipt of a customer order and ends with customer receipt of the product or service. Everything in between is the lead-time. Lead-time refers to the time lag between placing an order and receiving it $\mathrm{Li}$, (2000). Lead time is therefore defined as the time it takes from getting order from a customer and receiving the delivered product by that customer Azad, (2004). When the duration between the ordering period and the delivery varies from the expected time, then lead time variability occurs. Lead time variability therefore refers to the variations in lead time that can occur for purchased items and for those that are manufactured in-house Heard and Plossl, (1984). A major factor related to these variations is quality problems. Typically, either safety stock or lead time is utilized to cushion the impact of this variability. In either case, larger variability requires increased inventories. Heard and Plossl (1984) portray high lead-time variability as a major reason for a plant's inability to achieve inventory goals and to incur longer average throughput.

Nordaset al. (2006) indicates that Lead time is the amount of time between the placement of an order and the receipts of the goods ordered. It depends on the nature of the product e.g. whether it is made to order or if it is a from the shelf product. Lead time also depends on planning and supply chain management, logistics services and of course distance to customers and suppliers. Long lead time does not need to be a problem if delivery is predictable and demand is stable. However, if there is uncertainty about future demand, long lead time is costly even when the customer knows exactly when the merchandise will arrive. If future demand has been underestimated, running out of stock has costs in terms of foregone sales and the possibility of losing customers. If 
future demand has been overestimated, excess supply must be sold at a discount. Furthermore, the longer the lead time and the more varieties of the product in question are on the market, the larger stocks are needed. It is also important to notice that competitiveness on lead time is not a static concept. When some firms are able to shorten lead time, others must follow in order to avoid punishment in terms of discounted prices or at worst exclusion from the bidding process. The latter can happen when a critical mass of suppliers is able to deliver just-in-time and the customer finds it safe to reduce inbound inventories to a couple of days or in some cases even a couple of hours.

Procurement processes of acquisition of goods and services strictly adhere to the Public Procurement and Disposal Act 2005 and Rules Regulations 2006 which is an impediment to pragmatic decisions and faster growth. The procurement processes are express and are executed in a sequence in order to avoid duplication of roles and for record keeping purposes. Contravention of the Act is severely punishable by imposing heavy fines on individuals and entities who error. The fear of being blacklisted and paying heavy fines instills fear in procurement officers in the way they execute their duties and mandates to the detriment of the general public who deserve services. Supplier selection is marred with corrupt tendencies though most respondents gave it a clean bill of health; it is an area which needs improvement. Automation and going paperless can unlock the stalemate and provide an avenue of ventilating on the vice.

Lysons and Farrington (2006) asserted that delivery lead times can be reduced through close cooperation with suppliers and possibly by inducing or having suppliers located closer to the factory. They also note that for JIT to be successful lead time must be zero or reduced to the bare minimum. Reducing lead-time can improve competitive advantage. An institution that can offer significant shorter and more reliable service delivery times than the others will often be able to increase its corporate image in the face of partners and stakeholders. They say it also alleviates high scups, high inventory and long lead times.

JING-sheng (1994) in his paper "the effect of Lead Time uncertainty in a simple stochastic Inventory Model", studied the dynamic inventory model with a stochastic lead time and demand. He aimed at finding out the effect of lead times and their variabilities on optimal inventory decisions and system performance. His findings were that stochastically larger lead times may not necessarily lead to higher optimal average costs as a result of the dominance of the variability effect. Similarly a more variable lead time always leads to a higher optimal average cost and vice-versa. However, the effect of lead-time variability on optimal average cost is a factor of inventory cost structure. This demonstration that reduced lead times and their variability is a key factor in the processes involvement which is the nerve centre of the Just in time technique which the researcher studied. It is on this premise that this study examined the average lead time of goods and services from the time of the requisitioning to delivery to the user.

\subsubsection{Effect of Transparencyn Organization Performance}

Transparency is commonly used to denote the total disclosure of financial and non financial information regarding governments' decision-making procedures and transactions, the roles of various. State bodies, the terms used in the budget law in a timely and systematic way Kopits and Craig, (1998). Albeit it is a well-known and used term, definition of transparency is not so straightforward: not only because of the difficulty in defining difference between expenditure side and revenue side, but also between transparency and process transparency De Simone, (2009).

The majority of works on fiscal transparency, as part of the budgetary institutions, belongs to the political economy domain4 using a class of models known as political agency models, which were created by Barro and Ferejohn (1986). These models are developed in an incomplete contract framework where transparency acts as a commitment device to "tie the hands" of policymakers tempted by deviations from socially optimal choices. The main empirical conclusions of this literature are that increasing transparency reduces debt accumulation and the scope for generating political budget cycles.

Transparency is generally defined as the open flow of information Piotrowski, (2007), and the literature on transparency in the relationship between governments and citizens has strongly emphasized this concept of openness. Oliver argues that ,transparency in an organization is not only about what's communicated externally, but about what's right on the inside, in the guts of its operationse (2004), and introduces the concept of ,new transparency ${ }^{\text {ee }}$ to describe the trend for organizations to face more active demands for disclosure of information. In the past many governments passively provided information only on request, and could do so at their own discretion, now they are being required to engage in more active disclosure. Piotrowski (2007) states that "governmental transparency equates to open government. The oft-cited definition of transparency by the Asian Development Bank (1995) is ,the availability of information to the general public and clarity about government rules, regulations and decisions." Transparency has become an important agenda in nearly every organization, public and private, large or small, with Hood (2006) suggesting it has ,attained quasi-religious significance in debate over governance and institutional design." Ball (2009) suggests transparency is starting to subsume accountability in public discourse about good governance. This sharply growing demand for transparency is based on many factors. First, transparency is one of the fundamental moral claims in democratic societies, with the peopl's right to have access to government information being widely accepted in representative democracies Pasquier \& Villeneuve, (2007). Second, transparency is one of the practical measures taken to curtail corruption, acting as a deterrent against corrupt behaviour by promoting citizens ${ }^{\text {ee }}$ vigilance, thus deterring public officials from misusing public service to attain private gain Florini, (2007).

According to Holzner and Holzner (2006), ,transparency is 
linked with the values of accountability, ${ }^{\text {ee }}$ as it allows citizens to monitor the quality of public services and encourages public employees to satisfy citizens. The literature on transparency advises that organizations should be transparent to increase the degree of trust Rawlins, (2008), though some scholars urge caution, citing the negative aspects of transparency, such as violation of privacy, direct cost of disclosure, and revelation of sensitive information Prat, (2006). Chambers (2004) reminds us that although publicity is in important principle in deliberative democracy, secrecy rather than publicity is often what is needed to ensure a high quality of deliberation. Heald (2006) stresses that „transparency is expected to contribute positively to trust by building credibility, ${ }^{\text {ec }}$ and it is to a consideration of the role of trust that we now turn.

Rawlins (2008) points out that trust, along with transparency, is an important indicator of a satisfactory relationship between a government and the public. Corruption, real or perceived, reduces citizens ${ }^{\text {ee }}$ perception of government performance in public services, negatively influencing citizens ${ }^{\text {ee }}$ trust. It frustrates the public, leading to reduced trust in governments. Note however that the observed decline in trust may not be simply caused by corruption but rather by a growth in cynicism. Whilst a government which is seen as corrupt will not be respected, it may still retain a sufficient level of trust to be able to function, for reasons such as „soundness of the democratic system and a respect for technocracy and expertise ${ }^{e e}$ Fieschi\& Heywood, (2004). By contrast, even when a government is seen as clean (not corrupt), citizens may not trust it due to cynicism arising from differences of political views, alienation, etc.

\subsubsection{Effect of Accountability on Performance of Public Institutions}

A number of scholars have studied performance-based accountability policies in a wide variety of public organizations at the state and federal level and have identified a number of problems with these types of policies. Radin (2006) presents a detailed and thorough discussion of the problems embedded in many performance/accountability discussions and identifies many of these issues that have been faced in higher education. She argues that many performance-accountability efforts are billed as a panacea for ailing organizations, but they often produce many negative consequences. Other work by scholars of performance management raises a host of other concerns, chief among them, the lack of evidence that performance budgeting/funding actually produces results Andrews and Hill (2003). Additionally, the use of performance data is often viewed as a more objective way to evaluate institutions, when, in fact, performance data often introduces considerable ambiguity, as individuals may often perceive performance indicators, or the determinants of these indicators, in different ways Moynihan (2006).

Additionally, the introduction of many of these policies fails to consider the critical differences among public institutions, especially with respect to mission and clientele, and these policies are often quite critical - to the point of being threatening - to leaders of public organizations (Radin (2006). The critical nature of these policies often establishes a culture of mistrust among elected officials and public administrators and can lead to a wide range of dysfunctional and counterproductive behaviors Meier and Bohte (2000). Additionally, we may be most likely to see these unintended consequences in more disadvantaged institutions Meier and Bohte (2000).

The existing work in public administration can substantially inform our discussions on accountability policies in higher education. While we have many reasons to expect the findings in work on other public agencies would also apply to public universities, there are some differences that are important to note. First, university presidents are rarely thought of as bureaucrats or even public managers, in a traditional sense. Second, public universities have traditionally enjoyed a high level of autonomy from government influence, and they are often highly regarded by citizens and policymakers alike. Yet, as public confidence in higher education has begun to erode and state budgets tighten, leaders of public universities have faced more scrutiny than they have in the past. Some may question whether "what we know" about traditional bureaucratic agencies can be applied to public universities, but the parallels are strong. The following section reviews the literature on performance funding in higher education, in which many of the themes discussed in the public administration literature come to the forefront in the higher education literature as well.

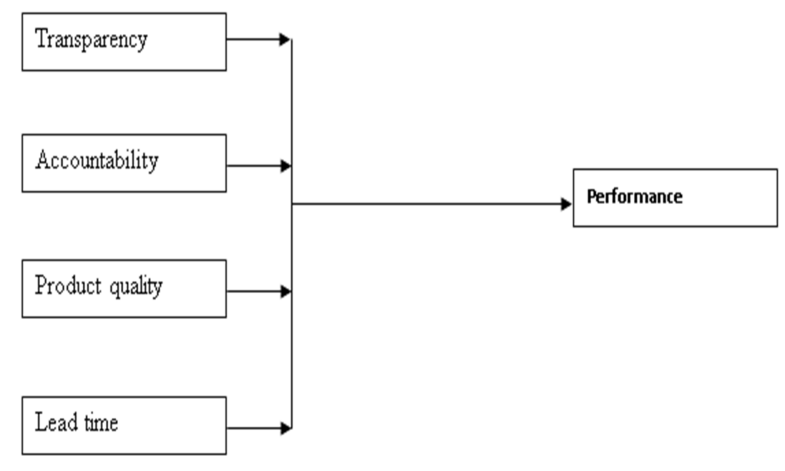

Fig. 1. Conceptual framework.

\section{Research Methodology}

\subsection{Research Design}

The research adopted a case study design. This is because it is easy to determine and carryout accurately and has greater efficiency and helps to meet the objective of the study. This was used in the research to get the view of different respondents who are involved in making and implementing of policies. The researcher aimed at investigating the role of tendering process on performance of public institutions.

\subsection{Target Population}

Target population according to Mugenda and Mugenda 
(1999), is the totality of cases of people, organizations or institutions, which poses certain characteristics relevant to the study. It is the total number of subjects of the interest to the researcher. The target population of the study comprised of 43 employees in the procurement department from the 10 Ministries in Nakuru County headquarters in Nakuru town. The table below shows the distribution of employees from each ministry.

Table 1. Target population.

\begin{tabular}{ll}
\hline Ministries & Target Population \\
\hline Education Sports Culture & 5 \\
Lands and Physical Planning & 3 \\
Finance and economic planning & 4 \\
Environment, Energy and Natural Resources & 6 \\
Public Service Management & 6 \\
Trade and Industrialization & 4 \\
Agriculture & 3 \\
Health & 4 \\
Public Service Board & 3 \\
Roads and Public works & 5 \\
Total & 43 \\
\hline
\end{tabular}

Source: County Government of Nakuru Records (2013)

\subsection{Sampling Design and Procedures}

According to Kull (1989) sampling is the process by which a relatively small number of individual, subjects or events is selected and analyzed in order to find out something about the entire population from which it was selected. A sample is a small population of the target population. Considering the target population which was small, the researcher used a census sampling technique where 43 numbers of respondents was arrived at.

\subsection{Data Collection Instruments and Procedures}

The main instrument used for data collection was a closed ended questionnaire where limited responses were required. The researcher administered the questionnaires on a drop and pick later basis to give the respondents adequate time to fill in the questions without pressure.

Reliability as described by Mugenda and Mugenda (1999) is a measure of degree to which an instrument yields consistent results or data after repeated trials. Validity is the degree to which results obtained after data analysis actually represents the phenomenon under study.

To ascertain the validity and reliability of the instrument, the researcher ensured that there is clarity and no error was detected. The questionnaire that had been prepared by the researcher was presented to the research supervisor who scrutinized and ratified that the questionnaire covered all the objectives. To test the reliability of the instrument, a pilot study was done in the neighboring Nyandarua County in Ol-kalou, where 12 questionnaires were issued to employees in the procurement department.

\subsection{Data Analysis and Presentation}

Data collected from the field was re-checked then edited and coded for completeness and kept for further analysis and interpretation of the study. It was then summarized and analyzed using descriptive statistics such as frequencies and percentages. Correlation analysis was conducted to establish the relationship between the variables. Data presentation was done using tables, graphs and charts which facilitated clear interpretation of results and drawing conclusions. These findings were later used to establish the role of tendering process on performance of public institutions.

\section{Research Findings}

\subsection{Effects of Transparency on Performance of Public Institutions}

The researcher further sought to determine whether transparency played a role in the performance of public institutions and the findings were as shown in the figure below.

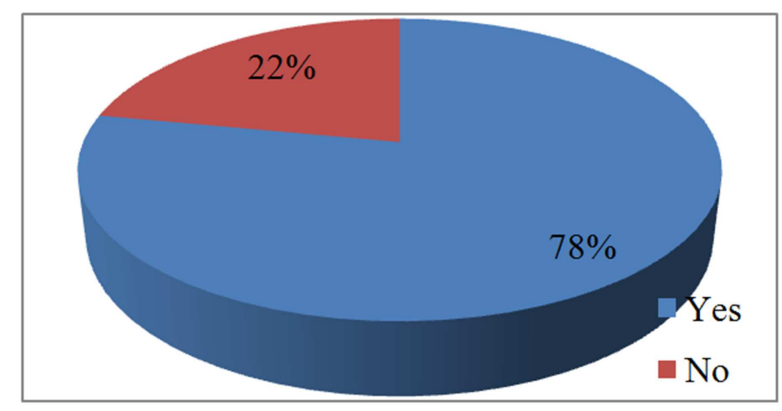

Source: Research Data (2015)

Fig. 2. Effects of Transparency on Performance of Public Institutions.

From the findings, $78 \%$ of the respondents indicated it played a role in the performance of public institutions while $22 \%$ cited it did not played a role in the performance of public institutions. This implies that majority of the respondents cited that transparency played a role in the performance of public institutions.

\subsection{Extent to Which Transparency Played a Role in Performance of Public Institutions}

The researcher sought to determine the extent to which transparency played a role in the performance of public institutions and the findings were a shown in the figure below.

From the findings, $33 \%$ of the respondents cited to a very large extent, $41 \%$ cited to a large extent, $22 \%$ to moderate extent, $4 \%$ of the respondents cited to a small extent and none of the respondents cited to a very small extent. This implies that majority of the respondents indicated that transparency played a role in performance of public institutions to a large extent. 


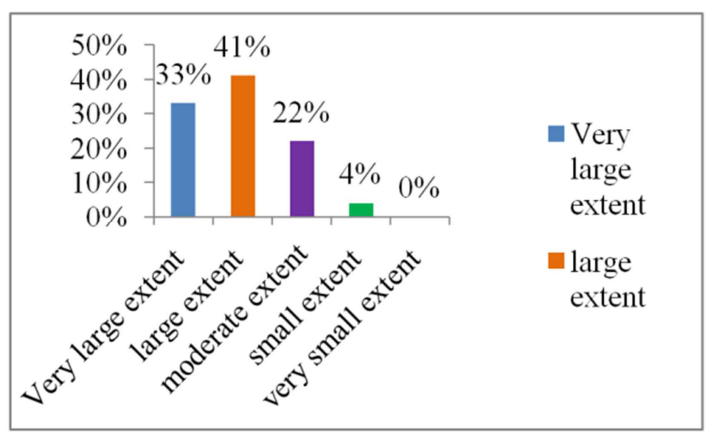

Source: Research Data (2015)

Fig. 3. Extent to which Transparency played a role in Performance of Public Institutions.

\subsection{Level of Transparency in the Flow of Information in Tendering}

The researcher sought to establish the level of transparency of flow of information on tendering in your and the findings were as shown in the figure below.

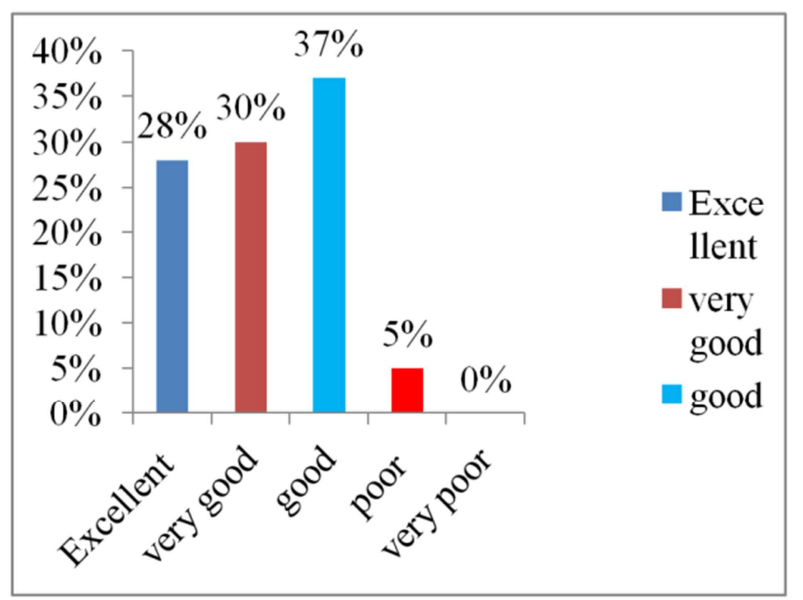

Source: Research data (2014)

Fig. 4. Level of Transparency in the flow of Information in Tendering.

From the findings, $28 \%$ of the respondents excellent, $30 \%$ cited they was very good, $37 \%$ indicated good, $5 \%$ of the respondents indicated it was poor, and none of the respondents cited very poor. This shows that majority of the respondents indicated the level of transparency was good.

\subsection{Statements on the Role of Transparency on Performance of Public Institutions}

The researcher further sought to determine the level to which respondents agreed on the statements regarding how transparency played a role in the performance of public institutions and the findings were as shown in the table below.

When the researcher sought to determine whether transparency reduces corruption during public tendering process hence resulting to the performance of public institutions, $43 \%$ of the respondents strongly agreed, $32 \%$ agreed, $5 \%$ were undecided, $12 \%$ disagreed and $8 \%$ strongly disagreed. On whether transparency deters public officialsfrom misusing public services thus resultingto positive performance of public institutions, $33 \%$ of the respondents strongly agreed, 36\% agreed, $21 \%$ were undecided, $8 \%$ disagreed, and $2 \%$ of the respondents strongly disagreed.On whether transparency play a role in the monitoring of quality of product and services during tendering process, $42 \%$ of the respondents strongly agreed, $33 \%$ agreed, $12 \%$ were undecided, and $13 \%$ disagreed.

Table 2. Statements on the role of Transparency on Performance of Public Institutions.

\begin{tabular}{llllll}
\hline & SA & A & U & D & SD \\
\cline { 2 - 6 } Statements & F (\%) & F (\%) & F(\%) & $\begin{array}{l}\text { F } \\
(\%)\end{array}$ & F(\%) \\
\hline $\begin{array}{l}\text { Transparency reduces } \\
\text { corruption during public } \\
\text { tendering process hence } \\
\text { resulting to the performance } \\
\text { of public institutions }\end{array}$ & $18(43)$ & $14(32)$ & $2(5)$ & $5(12)$ & $3(8)$ \\
$\begin{array}{l}\text { Transparency deters public } \\
\text { officialsfrom misusing } \\
\text { public services thus } \\
\text { resultingto positive } \\
\text { performance of public } \\
\text { institutions }\end{array}$ & $14(33)$ & $15(36)$ & $9(21)$ & $3(8)$ & $1(2)$ \\
$\begin{array}{l}\text { Transparency play a role in } \\
\text { the monitoring of quality of } \\
\text { product and services during } \\
\text { tendering process }\end{array}$ & $18(43)$ & $14(33)$ & $5(12)$ & $5(13)$ & $0(0)$ \\
\hline
\end{tabular}

Source: Research Data (2015)

\subsection{Effects of Accountability on the Performance of Public Institutions}

Further the researcher sought to establish whether accountability resulting from tendering process played a role in the performance of public institutions and the findings were as shown in the figure below.

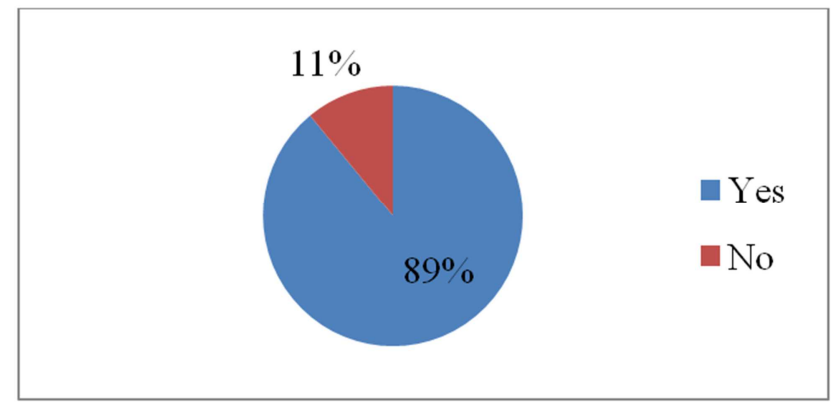

Source: Research Data (2015)

Fig. 5. Effects of Accountability on the Performance of Public Institutions.

From the findings, $89 \%$ of the respondents indicated that accountability resulting from tendering process played a role in the performance of public institutions while $11 \%$ cited that it had no effect. This implies majority of the respondents indicated that accountability resulting from tendering process played a role in the performance of public institutions. 


\subsection{Extent to Which Accountability Played a Role in the Performance of Public Institutions}

When the researcher sought to establish the extent to which accountability resulting from tendering process played a role in the performance of public institutions the findings were as shown in figure below.

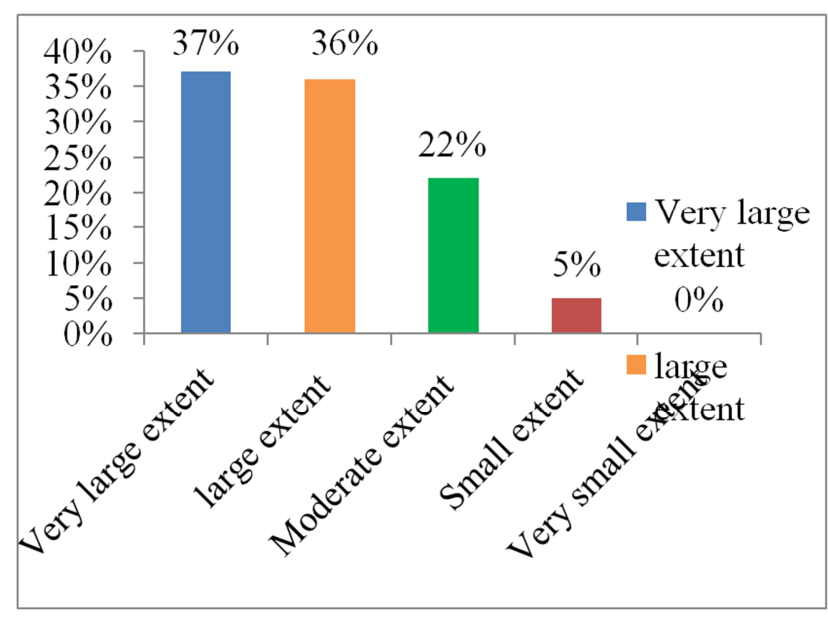

Source: Research Data (2015)

Fig. 6. Extent to which Accountability played a role in the Performance of Public Institutions.

The findings revealed that, $37 \%$ of the respondents indicated to a very large extent, $36 \%$ cited to a large extent while $22 \%$ cited to a moderate extent, $5 \%$ cited to a small extent and none of the respondents indicated to a very small extent. This results shows that majority of the respondents indicated that resulting from tendering process played a role in the performance of public institutions.

\subsection{Level of Accountability of Procurement Officers}

The researcher sought to determine the level of accountability of procurement officers in the organization and the findings were as shown in the table below.

Table 3. Level of Accountability of Procurement Officers.

\begin{tabular}{lll}
\hline Level & Frequency & Percentage (\%) \\
\hline Excellent & 18 & 42 \\
Very good & 14 & 33 \\
Good & 9 & 21 \\
Poor & 1 & 4 \\
Very poor & 0 & 0 \\
Total & 42 & 100 \\
\hline
\end{tabular}

Source: Research Data (2015)

From the findings, $42 \%$ of the respondents indicate it was excellent, $33 \%$ of the respondents stated it was very good, $21 \%$ stated it was good, $4 \%$ cited it was poor and none of the respondents indicated it was very por. This implies that majority of the respondents indicated that the level of accountability of procurement officers in the organization was excellent.

\subsection{Level of Agreement on Statements Effects of Accountability on Performance}

An analysis was made by the researcher to establish the level to which the respondents agreed on statements on how accountability resulting from tendering process played a role in the performance of public institutions and the findings were as shown in the table below.

Table 4. Effects of Accountability on Performance of Public institutions.

\begin{tabular}{|c|c|c|c|c|c|}
\hline \multirow[t]{2}{*}{ Statements } & SA & $\mathbf{A}$ & $\mathbf{U}$ & D & SD \\
\hline & F (\%) & F (\%) & $\mathbf{F}(\%)$ & F (\%) & $F(\%)$ \\
\hline $\begin{array}{l}\text { Public administration on tendering process leads to accountability during the } \\
\text { tendering process and hence positive performance of public institutions }\end{array}$ & $13(31)$ & $15(35)$ & $4(10)$ & $5(12)$ & $5(12)$ \\
\hline $\begin{array}{l}\text { Audit of public institutions leads to accountability in the public service } \\
\text { delivery hence resulting to better performance of public institutions }\end{array}$ & $9(21)$ & $15(35)$ & $6(14)$ & 11(26) & $1(4)$ \\
\hline $\begin{array}{l}\text { Strict procedures followed in public procurement leads to accountabilitythus } \\
\text { contributing to good performance of public institutions }\end{array}$ & $15(35)$ & $15(35)$ & $6(14)$ & $5(12)$ & $1(4)$ \\
\hline
\end{tabular}

Source: Research Data (2015)

When the researcher sought to determine whether Public administration on tendering process leads to accountability during the tendering process and hence positive performance of public institutions, $31 \%$ strongly agreed, 35\% agreed, $10 \%$ were undecided, $12 \%$ disagreed, while $12 \%$ strongly disagreed. On whether audit of public institutions leads to accountability in the public service delivery hence resulting to better performance of public institutions $21 \%$ of the respondents strongly agreed, 35\% agreed, $14 \%$ were undecided, 26\% disagreed and 4\% strongly disagreed. In trying to establish whether strict procedures followed in public procurement leads to accountability thus contributing to good performance of public institutions, 35\% strongly agreed, 35\% agreed, $14 \%$ were undecided, $12 \%$ disagreed and $4 \%$ strongly disagreed.

\subsection{Effects of Lead Time on Performance of Public Institutions}

Further the researcher sought to establish whether lead time resulting from tendering process played a role in the performance of public institutions and the findings were as shown in the figure below.

From the findings, $83 \%$ of the respondents indicated that lead time resulting from tendering process played a role in the performance of public institutions while $17 \%$ cited that it had no effect on performance. This implies majority of the 
respondents indicated that lead time resulting from tendering process played a role in the performance of public institutions.

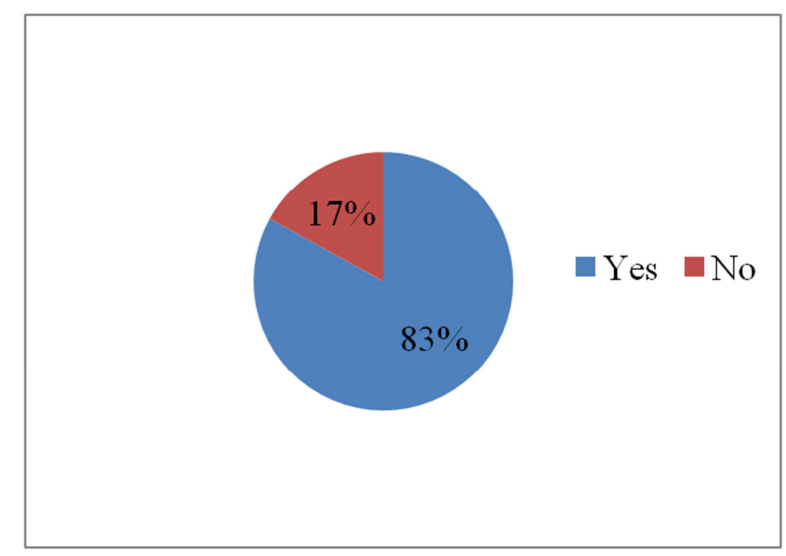

Source: Research Data (2015)

Fig. 7. Effects of Lead time on Performance of Public Institutions.

\subsection{Extent to Which Lead Time Affect Performance of Public Institutions}

When the researcher sought to establish the extent to which lead time resulting from tendering process played a role in the performance of public institutions the findings were as shown in figure below.

The findings revealed that, $42 \%$ of the respondents indicated to a very large extent, $36 \%$ cited to a large extent while $16 \%$ cited to a moderate extent, $4 \%$ cited to a small extent and $2 \%$ of the respondents indicated to a very small extent. This results shows that majority of the respondents indicated that lead time resulting from tendering process played a role in the performance of public institutions to a very large extent.

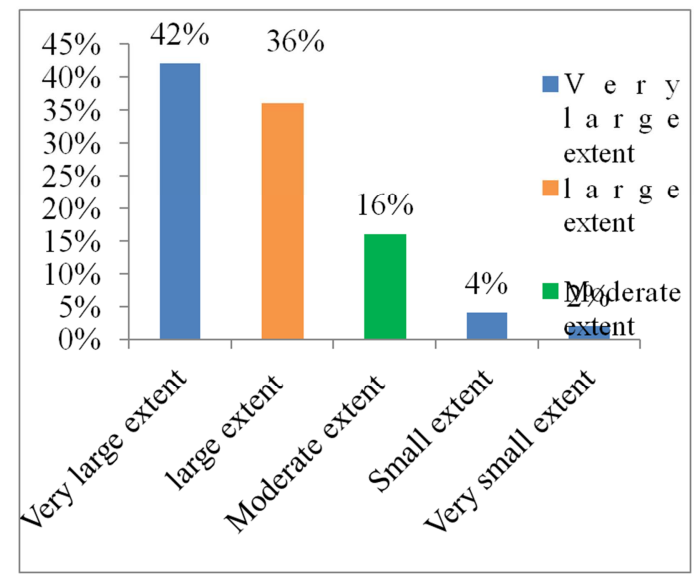

Source: Research Data (2015)

Fig. 8. Extent to which Lead time affect Performance of Public institutions.

\subsection{Statements on Effects of Lead Time on Performance of Public Institutions}

The researcher was further interested in determining how respondents agreed on statements on how lead time resulting from tendering process played a role in the performance of public institutions and the findings were as shown in the table below.

Table 5. Statements on Effects of Lead time on performance of Public Institutions.

\begin{tabular}{|c|c|c|c|c|c|}
\hline \multirow[t]{2}{*}{ Statements } & SA & $\mathbf{A}$ & $\mathbf{U}$ & D & SD \\
\hline & F (\%) & F (\%) & $\mathbf{F}(\%)$ & $F(\%)$ & $\mathbf{F}(\%)$ \\
\hline $\begin{array}{l}\text { Supply of goods and services on time plays a role in the performance of public } \\
\text { institutions }\end{array}$ & $13(32)$ & $15(36)$ & $9(21)$ & $5(11)$ & $0(0)$ \\
\hline $\begin{array}{l}\text { The ability of a supplier to deliver quickly improve the performance of public } \\
\text { institutions }\end{array}$ & $14(33)$ & $15(36)$ & $8(21)$ & $3(8)$ & $1(2)$ \\
\hline $\begin{array}{l}\text { High lead time variability due to tendering is a major reason for an organization } \\
\text { inability to achieve inventory goals and hence affect the performance of public } \\
\text { institutions negatively }\end{array}$ & $17(42)$ & $14(33)$ & $5(12)$ & $6(13)$ & $0(0)$ \\
\hline $\begin{array}{l}\text { High lead timeresulting from tendering process incur longer average throughout } \\
\text { and hence resulting to poor performance of publicinstitutions }\end{array}$ & $9(21)$ & $15(35)$ & $6(14)$ & 11(26) & $1(4)$ \\
\hline
\end{tabular}

Source: Research Data (2015)

On whether supply of goods and services on time plays a role in the performance of public institutions, $32 \%$ of the respondents strongly agreed, $36 \%$ of the respondents agreed, $21 \%$ were undecided, $11 \%$ disagreed, and none strongly disagreed. On whether the ability of a supplier to deliver quickly improve the performance of public institutions, $33 \%$ of the respondents strongly agreed, and 36\% agreed, $21 \%$ were undecided, $8 \%$ disagreed, and $2 \%$ of the respondents strongly disagreed. On whether High lead time variability due to tendering is a major reason for an organization inability to achieve inventory goals and hence affect the performance of public institutions negatively, $42 \%$ of the respondents strongly agreed, $33 \%$ agreed, $12 \%$ of the respondents were undecided,
$13 \%$ disagreed and none of the respondents strongly disagreed. On whether High lead timeresulting from tendering process incur longer average throughout and hence resulting to poor performance of publicinstitutions $21 \%$ of the respondents strongly agreed, 35\% agreed, $14 \%$ were undecided, $26 \%$ disagreed and $4 \%$ strongly disagree.

\subsection{Quality Assurance in the Organization}

The researcher further sought to determine whether the organization had quality assurance and the findings were as shown in the figure below.

From the findings, $78 \%$ of the respondents indicated the 
organization had quality assurance while $22 \%$ cited it did quality assurance. This implies that the organization had quality assurance policy.

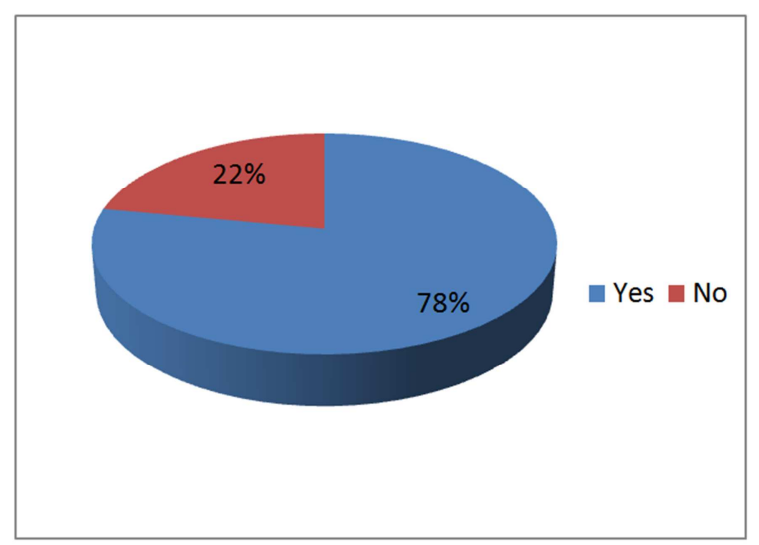

Source: Research Data (2014)

Fig. 9. Quality Assurance in the Organization.

\subsection{Level of Effectiveness of Quality Assurance Policy}

The researcher sought to establish the accountability level of effectiveness of quality assurance policy in the organization in enhancing quality of goods and services and the findings were as shown in the figure below.

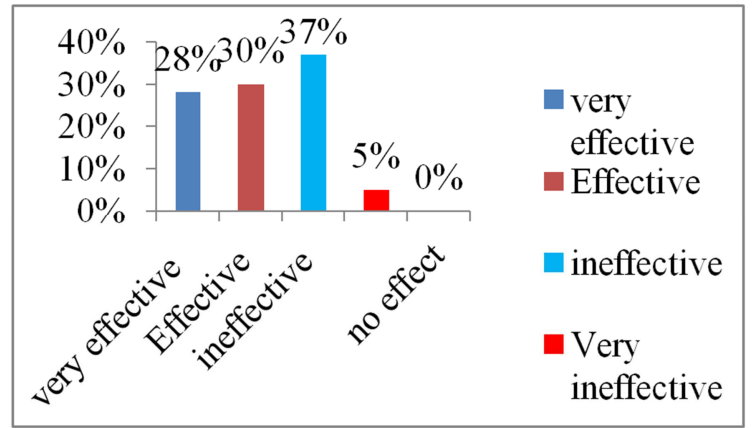

Source: Research data (2014)

Fig. 10. Level of Effectiveness of Quality Assurance policy.

From the findings, $28 \%$ of the respondents indicated very effective, $30 \%$ cited they was effective, $37 \%$ indicated ineffective, $5 \%$ of the respondents indicated it was very ineffective, and none of the respondents cited no effect. This shows that majority of the respondents indicated the quality assurance policy were ineffective.

Table 6. Summary of correlation analysis.

\begin{tabular}{|c|c|c|c|c|c|c|}
\hline & & Transparency & Accountability & Quality & Lead time & Performance \\
\hline \multirow[t]{3}{*}{ Transparency } & Pearson Correlation & 1 & & & & \\
\hline & Sig. (2-tailed) & & & & & \\
\hline & $\mathrm{N}$ & 80 & & & & \\
\hline \multirow[t]{3}{*}{ Accountability } & Pearson Correlation & .052 & 1 & & & \\
\hline & Sig. (2-tailed) & .645 & & & & \\
\hline & $\mathrm{N}$ & 80 & 80 & & & \\
\hline \multirow[t]{3}{*}{ Qualitty } & Pearson Correlation & .132 & -.013 & 1 & & \\
\hline & Sig. (2-tailed) & .242 & .907 & & & \\
\hline & $\mathrm{N}$ & 80 & 80 & 80 & & \\
\hline \multirow[t]{3}{*}{ Lead time } & Pearson Correlation & .039 & -0.197 & -.052 & 1 & \\
\hline & Sig. (2-tailed) & .733 & .000 & .647 & & \\
\hline & $\mathrm{N}$ & 80 & 80 & 80 & 80 & \\
\hline \multirow[t]{3}{*}{ Performance } & Pearson Correlation & .350 & .585 & $.497^{*}$ & $.405^{*}$ & 1 \\
\hline & Sig. (2-tailed) & .077 & .209 & .000 & .000 & \\
\hline & $\mathrm{N}$ & 80 & 80 & 80 & 80 & 80 \\
\hline
\end{tabular}

**. Correlation is significant at the 0.01 level (2-tailed).

*. Correlation is significant at the 0.05 level (2-tailed).

The results in Table 4.9 indicate that each of the four tendering process variables coefficients were highly significant indicating that the organizational performance in the organization was highly influenced by the extent to which the organization adopted tendering process. Transparency positively correlated with organizationalperformance $(\mathrm{r}=0.350, \mathrm{p}=0.077, \alpha=0.05)$ while accounatbility also positively correlated with the organizational performance ( $\mathrm{r}=$ $0.585, \mathrm{p}=0.209, \alpha=0.05$ ). Quality and lead time also correlatedpositively correlated with organizational 
performance performance $(r=0.497$ and $r=0.405 \mathrm{p}=0.000, \alpha$ $=0.05)$ respectively. These results reveal that adoption of tendering process will positively influence organizational performance.

\section{Conclusions and Recommendations}

Based on the findings, the researcher concluded that the level of transparency in the organization was good. The findings further revealed that transparency reduced corruption during tendering process hence resulting to enhance the performance of public institutions. The researcher concluded that transparency resulting from tendering process played a role in the performance of public institutions to a very large extent.

Further the researcher concluded that Public administration on tendering process leads to accountability during the tendering process and hence positive performance of public institutions. The researcher concluded that accountability resulting from tendering process played a role in the performance of public institutions to a very large extent.

The research findings further revealed that high lead time variability due to tendering is a major reason for an organization inability to achieve inventory goals and hence affect the performance of public institutions negatively. The researcher concluded that lead time resulting from tendering process played a role in the performance of public institutions to a very large extent.

The research findings further also revealed that compliance with tendering procedures ensures quality thus enhancing organization performance. The researcher concluded that lead time resulting from tendering process played a role in the performance of public institutions to a very large extent.

\subsection{Recommendation}

Based on the findings, the researcher recommended that the county government employees need to be more transparent in the tendering process. The organization should be able to put in place measures to enhance transparency during the tendering process.

The researcher further recommended there was need for the organization employees to be more accountable during tendering process. This will help in enhancing the effectiveness of the process thus better performance.

Further, the researcher recommended that there was need for the organization to minimize lead time by initiating review of the procurement law to hasten the tendering process. Short lead times will enhance the speed of delivery in the institution which in turn enhances overall organization performance of the public institution.

Finally, the researcher recommended that there was need for the institutions to maintain high quality. Clear policies on quality standards in the organization should be always instilled on the employees in order to ensure that they always perform better.

\subsection{Suggestions for Further Studies}

The researcher recommended that a replication of the study to be carried out in other areas to enable generalization of the findings.

The researcher recommended a further research to be carried out on the role played of other alternative procurement methods on performance of public institutions.

Further studies should be conducted on the critical success factors of tendering in public institutions.

\section{References}

[1] Ahmed, Irfan and Parasuraman (1994) Environment and Positional Antecedents off Management Commitment to Service Quality. A conceptual framework. In advances in services marketing and management Vol.3.

[2] Amstrong (2004), Marketing and Introduction, 4th edition, Harvard Business School press: New Jersey, USA.

[3] Barasa, H. W. (2014). Procurement Practices Affecting Effective Public Projects Implementation in Kenya: A Case Study of Kenya Civil Aviation Authority. European Journal ofBusiness and Management ISSN 2222- 2839 (Online).

[4] Bell (2001).Impact of the internet on purchasing practices. Acquisitions Review Quarterly 5 (2).

[5] Borg and Crall (1959) Research Procedures, Prentices Hall: New York, USA.

[6] Business, Corruption and Russia (2012) Sales Management 3rd edition, publisher Taylor: New York, USA.

[7] Charles Vee and Martin Skitmore (2003) Professional ethics in the construction and architectural management Vol. 10.

[8] Christopher (2004).Public Procurement Handbook. Chancery Law Pub., Colorado Springs.

[9] Cole G. (2002), Management Theory 5th edition, DP publishers: New York USA.

[10] D.W., Burt, D.D. (Eds.), Purchasing and Supply Chain Management-Text and Cases.

[11] Egbu et al (2003). The factors influencing bid mark-up decisions of large and medium size. Purchasing and supplies journal.

[12] Erridge, A., Fee, R., McIlroy, J., 2001. Best Practice Procurement: Public and Private Sector Perspectives. Gover Pub Co., Burlington, VT. European Communities, 2002.eEurope 2005. Francis Group.

[13] GOK (2005b) Public officer Ethics Act, Government press: Nairobi.

[14] GOK, (2005a) Anticorruption and Economics Crime Act, Government press: Nairobi.

[15] Gordon, S.P., 1996. Purchasing for institutions and governmental organizations. In: Dobler, D.W., Burt, D.D. (Eds.), Purchasing and Supply Chain Management-Text and Cases. McGraw-Hill, New York, pp. 743-770. 
[16] Heraty (1995).European Logistics Software Guide 2000 (ISBN I-862130-48-5), pp. 67-71. Institute of Governmental Purchasing, Inc.

[17] John N. (2003) Management, 9th edition, Ashford color press: Hampshire UK.

[18] Kathuri and Pal (1993) Introduction to education research, Egerton University, Njoro.

[19] Kerlinger R. (1983) Foundation of Behavioral Research, Richatt and Wintson: New York, USA.

[20] Kiage, J. O. (2013). Factors Affecting Procurement Performance: A Case of Ministry of Energy. International Journal of Business and Commerce. Vol. 3, No. 1: Sep 2013 [54-70].

[21] Kibera F. N. and Waruingi B.C (2005), Fundamentals of Marketing, Kenya Literature Bureau.

[22] Knudsen (2003).A study of factors affecting success in tendering. Doctoral thesis, UMIST.

[23] Kombo and Tromp (2011), Proposal and Thesis writing. Pauline's Publication Africa.

[24] Kothari C.R. (2004) second revised edition. Research methodology, methods and techniques. New Delphi: New Age International.

[25] Kotler P. (2003), Marketing Management, International Edition, 11th Edition, Prentice Hall: New Jersey, USA.

[26] Latham (1994).Decision and Risk Analysis for Construction Management: New York, USA.

[27] Lysons, K. and Farrington, B, (2006), Purchasing and Supply Chain Management, Prentice Hall,seventh Edition: Manchester.

[28] Malala, A, (2011); Effect of Procurement on Performance of Constituency Development Fund Projects in Kenya: Case Study of Kikuyu Constituency. Retrieved from Jomo Kenyatta University of Agriculture and Technology, Department of Entrepreneurship and Procurement.

[29] Mark S. (2004) Procurement Practice, third edition, Desktop Publishers: Madrid, Spain.

[30] McKay, J., 2001. Getting through the maze, pp 46-48, Government Technology (January).
[31] Mizra (2008).Government contracting and procurement: A critical process for both the public and private sectors. International Journal of Public.

[32] Muffumba (2002), procurement Management, 4th edition, Ashford Colour press: Hampshire.

[33] Mugenda and Mugenda (2003) Research methods, qualitative and quantitative approaches, Fourth edition, Ashford color press: New Jersey, USA.

[34] Musembi (2005) Effective inters firm collaboration: how firms minimize transaction costs: Nairobi.

[35] Nzau, A. \& Njeru, A. (2014). Factors affecting procurement performance of public universities in NairobiCounty. International Journal of Social Sciences and Project Planning Management, 1 (3), 147-156.

[36] Public Procurement Disposal Act (2005) Assessment of the Procurement System in Kenya Nairobi: PPDA.

[37] Rankin (2006).Factors considered in tendering decisions. Management and Economics.

[38] Rusell (2003), Marketing Strategy 4th Edition, DP publishers: Libson.

[39] Seloba (2006) "Pan examination of the impact of the political interference in administration with specific focus on the department of health and social development in Limpopo".

[40] Tata (1996).Improving organizational effectiveness of public enterprises in Kenya. Thesis business and economic sciences.

[41] Thai (2005).Business models for Data monitor, 2000. Global online procurement-market opportunities to 2004 (DMTC0632 Published 01/2000), pp. 40. Development initiatives on purchasing performance: a structural model. Supply Chain.

[42] Walter (1984).Is re-engineering possible in the public sector? A Brazilian case study. Business Change and Re-engineering three (3), 3-12.

[43] World Bank (2008) Public sector reform: What works and what does not? An independent Evaluation Group, Evaluation of the World Bank: Washington DC.

[44] World Forum (2012).Planning, Scheduling \& Requirement Analysis. Herndon, VA: National journal. www.mwi.comMinistry of Water and Irrigation Website. 